\title{
VAŽNOST PRIKUPLJANJA SREDSTAVA (FUNDRAISING) ZA DJELOVANJE NEPROFITNIH ORGANIZACIJA PRIMJER GLOBALNOG POKRETA MARY'S MEALS
}

\author{
Miro Radalj
}

Sveučilište u Mostaru

UDK: 341.232:332.834.7Mary's Meals

Filozofski fakultet https://doi.org/ 10.34075/cs.55.2.7

Pregledni znanstveni rad Rad zaprimljen 10/2019.

\section{Sažetak}

Prikupljanje sredstava (fundraising) vrlo je važna aktivnost neprofitnih organizacija jer bez financijskih sredstava teško bismo mogli ostvariti svoju misiju. Planiranje prikupljanja sredstava čest je posao djelatnika za odnose s javnošću u neprofitnim organizacijama.

Za uspješno prikupljanje sredstava neizostavan je jasno definiran razlog za potporu (case for support).

Negativan publicitet povezan s troškovima kampanje može imati učinak na napore organizacija u prikupljanju sredstava jer ona najčešće ovise o potpori javnosti. Uobičajena visina troškova kampanje ne bi smjela prelaziti 12 - 15\% ukupno prikupljenih sredstava, a troškovi do $20 \%$ postali su gornja prihvatljiva razina. Prikupljanje sredstava mora poštovati etičke standarde, a troškovi se moraju kontrolirati. Brojne nevladine organizacije upravo su na etičkim standardima izgubile reputaciju, nestale sa scene i nanijele štetu cijelomu neprofitnom i humanitarnom sektoru.

Jedan od najupečatljivijih primjera dobra prikupljanja i učinkovita korištenja prikupljenih sredstava međunarodna je humanitarna organizacija Mary's Meals (Marijini obroci).

Ključne riječi: neprofitne organizacije, fundraising, donacije, sponzorstva, Mary's Meals.

\section{UMJESTO UVODA: ŠTO JE FUNDRAISING?}

Neprofitne organizacije suočavaju se sa stalnom potrebom prikupljanja sredstava koja bi im pomogla u ostvarivanju ciljeva te ulažu značajan trud u prikupljanje priloga potrebnih za provedbu svoje misije. Čak su i javne institucije poput fakulteta i bolnica uočile da se ne mogu 
razvijati bez donacija. ${ }^{1}$ Često je u neprofitnim organizacijama planiranje prikupljanja sredstava posao djelatnika za odnose s javnošću.

Nedostatak financijskih sredstava u novije vrijeme sve više dolazi do izražaja, poglavito zato što neprofitne organizacije ovise o sredstvima iz javnoga proračuna (dotacije), ali i zato što je prisutan sve veći broj registriranih neprofitnih organizacija koje se natječu za sve manji raspoloživi iznos javnih sredstava. Slijedom toga, upitna je dugoročna održivost neprofitnih organizacija. ${ }^{2}$

Kako bi prikupljanje sredstava (fundraising) bilo učinkovitije, potrebno je voditi računa o tome da ono nije cilj sam po sebi, već da treba biti nadahnuto ostvarivanjem konkretnih ciljeva organizacije. Tako će prikupljanje biti inspirativno i poticajno onima koji sredstva nastoje prikupiti, kao i onima od kojih se prikuplja. Polazište uvijek treba biti ostvarivanje ciljeva, a ne prikupljanje sredstava, jer sredstva ne donose ideju i ne pronalaze ciljeve, iako su nužna za njihovo ostvarenje. ${ }^{3}$ Henri J. M. Nouwen navodi da je „prikupljanje sredstava sama suprotnost prošenju"4 zato što je to naviještanje onoga što vjerujemo te pružanje prigode drugim ljudima da sudjeluju s nama u našoj viziji i našem poslanju. ${ }^{5}$

Početak prikupljanja sredstava pripisuje se prvim imućnim pojedincima koji su donirali sredstva uglavnom vjerskim institucijama, sirotištima ili za osnivanje škola u 17. i 18. stoljeću, ali fundraising se kao planirana aktivnost javlja se tek početkom 20 . stoljeća. ${ }^{6}$ Zahvaljujući tim imućnim pojedincima koji su davali novac u dobrotvorne svrhe, razvija se filantropija ${ }^{7}$, tj. kultura dobrovoljnoga darivanja za opće dobro. ${ }^{8}$

Prepoznavanje motiva za doniranje važna je pretpostavka uspješna procesa prikupljanja sredstava. Da bi ovaj proces bio

$1 \quad$ Usp. Otis Baskin, Craig Arnoff, Dan Lattimore, Public Relations - The Profession and the Practice, McGrawHil, Boston, 1997., str. 384.

2 Usp. Lorena Dadić, „Važnost fundraisinga za održavanje neprofitnih organizacija“, u: Oeconomica Jadertina, vol. 6, br. 2, Odjel za ekonomiju Sveučilišta u Zadru, Zadar, 2016., str. 79.

3 Usp. Miro Radalj, Odnosi sjavnošću u neprofitnim organizacijama, Hrvatska udruga za odnose s javnošću i Hrvatska sveučilišna naklada, Zagreb, 2018., str. 97.

4 Henry J. M. Nouwen, Duhovnost prikupljanja sredstava, Krščanska sadašnjost, Zagreb, 2019., str. 27.

5 Usp. isto.

$6 \quad$ Usp. Nikša Alfirević i dr., Osnove marketinga i menadžment neprofitnih organizacija, Školska knjiga, Zagreb, 2013., str. 139.

7 Filantropija (grč.), čovjekoljublje, ponašanje koje potiče i širi djela pomaganja i ljubavi prema bližnjemu.

8 Usp. N. Alfirević, i dr., nav. dj., str. 131. 
uspješan, potencijalni donator/sponzor mora jasno razumjeti ciljeve organizacije i programa koje organizacija provodi te njihovu svrhu za cjelokupno društvo. ${ }^{9}$

Iako je glavni cilj fundraisinga prikupiti što više sredstava za djelovanje neprofitne organizacije (izravan utjecaj), njegov je kontekst puno širi i implicira više pozitivnih neizravnih utjecaja na organizaciju, a oni se ogledaju u jačanju vidljivosti organizacije, širenju njezine misije u društvu, reputaciji, kao i motiviranju mogućih budućih donatora. ${ }^{10}$

Podatci koji govore o razvoju fundraisinga u Hrvatskoj vrlo su ograničeni. Oni se uglavnom oslanjaju na razdoblje Domovinskog rata i naglo povećanje broja humanitarnih organizacija koje su se bavile posljedicama rata. Tada su mnoge međunarodne organizacije svojim donacijama pružale pomoć i olakšavale život u ratnim okolnostima. Poslije rata mnoge su se humanitarne organizacije ugasile, a njihovim ukidanjem smanjivale su se i donacije međunarodnih udruga. ${ }^{11}$

Financijska sredstva potrebna za svoj rad neprofitne organizacije osiguravaju iz sljedećih izvora:

- $\quad$ privatni - donacije gospodarskih subjekata i građana

- javni - državne dotacije koje daju Vlada, županije, gradovi i općine

- $\quad$ članarine - sredstva koja daju članovi pojedinih organizacija te

- $\quad$ strani izvori - sredstva koja se dobiju iz inozemnih programa namijenjenih razvoju civilnoga društva. 12

Prema podatcima Ministarstva financija RH za 2014. godinu u strukturi dotacija neprofitnih organizacija najveći udio čine prihodi od dotacija iz proračuna jedinica lokalne i regionalne samouprave (45\%), slijede prihodi od trgovačkih društava i ostalih pravnih osoba (16\%), prihodi od inozemnih vlada i međunarodnih organizacija (15\%), prihodi od dotacija iz državnoga proračuna (14\%), prihodi od građana i kućanstava (4\%) te ostali prihodi $(6 \%) .{ }^{13} \mathrm{Iz}$ ovoga je vidljivo da najveći dio prikupljenih sredstava čine oni iz javnog sektora $(57 \%)$.

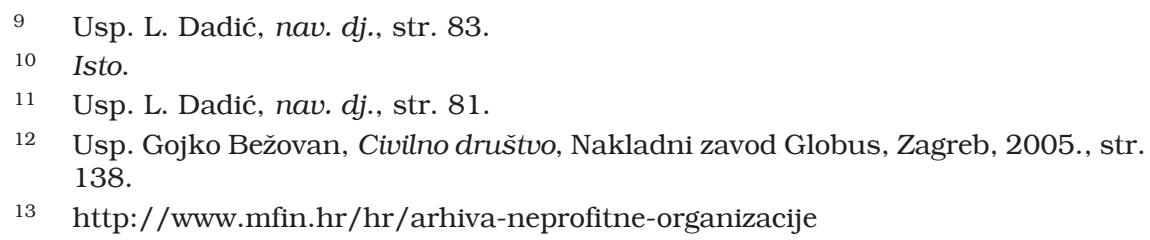




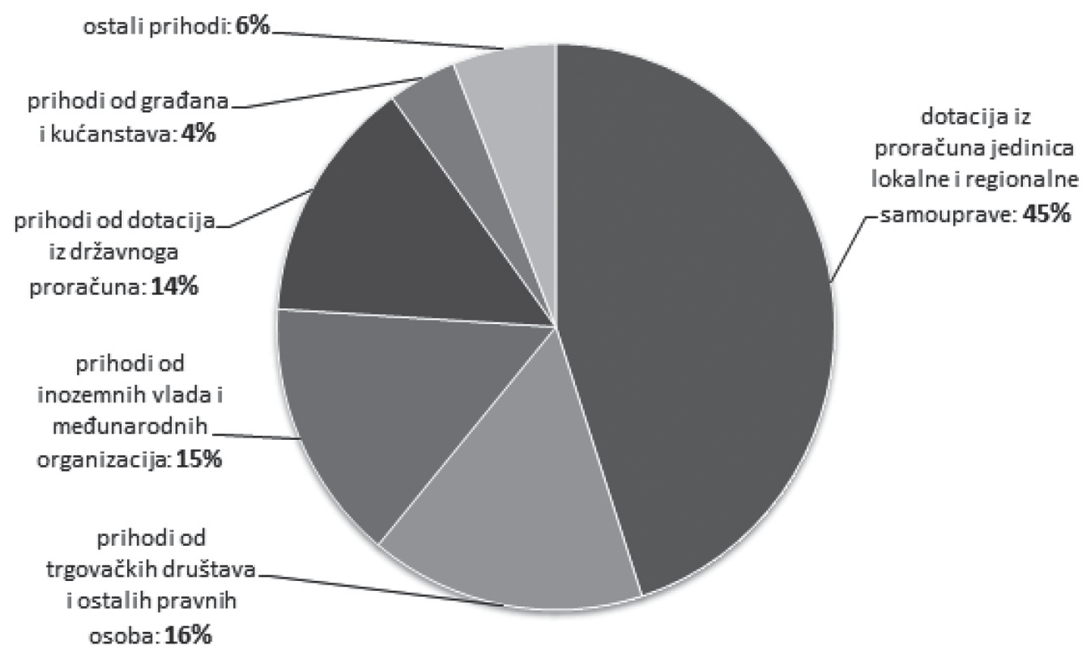

Grafički prikaz 1. Struktura dotacija neprofitnih organizacijama u Republici Hrvatskoj

Kada govorimo o organiziranom prikupljanju sredstava, najčešće se rabe dva termina, koje mnogi pogrešno drže sinonimima (istoznačnicama): donacije i sponzorstva.

Donacije (lat. donum - dar) predstavljaju darivanje novca, proizvoda ili usluga u dobrotvorne svrhe u korist pojedinaca ili organizacije od kojih donator ne očekuje povratnu financijsku korist. ${ }^{14}$ Pravnim se osobama darivanja (donacije) porezno priznaju kao rashod ako su učinjena u tuzemstvu za kulturne, znanstvene, odgojnoobrazovne, zdravstvene, humanitarne, sportske, vjerske, ekološke i druge općekorisne svrhe organizacijama i pojedincima koji navedene djelatnosti obavljaju u skladu s posebnim propisima, i to do najviše $2 \%$ od prihoda ostvarenog u prethodnoj godini. ${ }^{15}$

Sponzorstvo je način prikupljanja sredstava koje podrazumijeva neki oblik promidžbe, odnosno protučinidbe, pa se smatra gospodarskom djelatnošću. S obzirom na to da se podrazumijeva protu-

14 Usp. Sandra Cvetko, „Sponzorstva i donacije kao dio integrirane marketinške komunikacije“, u: Odnosi s javnošću za organizacije civilnog društva, ur. Boris Hajoš i Božo Skoko, Hrvatska udruga za odnose s javnošću, Zagreb, 2009., str. 68.

15 Usp. Olga Štajdohar-Pađen, „Kako do sponzora i donatora“, u: Udruga, Zagreb, br. 19/2016., str. 14. 
činidba, podrazumijeva se i potpisivanje ugovora kojim se zakonski regulira odnos između ugovornih strana. ${ }^{16}$ Sponzorstvo je davanje u novcu, stvarima ili uslugama pravnoj ili fizičkoj osobi uz određenu protuuslugu, promidžbenu, odnosno reklamnu. Troškovi se sponzorstva kod sponzora bilježe kao trošak promidžbe i u potpunosti su porezno priznati bez obzira na iznos, a primatelj novčanih sredstava dužan je sponzoru izdati račun za reklamiranje. ${ }^{17}$

Prema podatcima s portala Statista, tvrtke su u svijetu 2016. godine potrošile više od 60 milijarda američkih dolara na sponzoriranje umjetnosti, sporta, zabave i raznih događaja, što je znatan porast u odnosu na prethodnu godinu, kada se potrošilo oko 37 milijarda američkih dolara. ${ }^{18}$

Do sada nije razvijen teorijski okvir za mjerenje reakcije potrošača na sponzorske aktivnosti pa se kao alternativa u literaturi navode mjerne tehnike prikladne za vrednovanje učinaka sponzorstva. ${ }^{19}$ Metode koje se najčešće rabe u mjerenju učinaka sponzorstva, one su koje se temelje na izloženosti, tehnike praćenja i eksperimenti. ${ }^{20}$ Za razliku od aktivnosti kojima se žele postići kratkoročni marketinški ciljevi (promidžbene kampanje i sl.), sponzorstvom se najčešće promiču određene vrijednosti i stvaraju izravni odnosi s primateljima sponzorstva i posredni odnosi s publikom koja prati aktivnosti primatelja sponzorstva. Tako se potiče lojalnost kao temelj postizanja dugoročnih povratnih efekata sponzorstva. ${ }^{21}$

\section{OPSEG I KULTURA DARIVANJA NOVCA}

Krovna europska organizaciju fundraisinga EFA (European Fundraising Association), osnovana je 2002. godine u Belgiji s ciljem pružanja potpore nacionalnim udruženjima fundraisinga. Udruženje se brine o uspostavi zajedničke platforme za dijeljenje znanja i razmjenu iskustva o fundraisingu kao i o uspostavljanju standarda koji će pomoći fundraiserima da profesionalno djeluju. ${ }^{22}$

16 Usp. N. Alfirević, i dr., nav. dj., str. 129.

17 Usp. O. Štajdohar-Pađen, nav. mj.

18 Usp. Ivica Zdrilić, Dino Kevrić, Željko Vrkić, „Sponzorstvo u sportu na primjeru košarkaških klubova“, u: Oeconomica Jadertina, br. 2/2017., str. 55.

19 Usp. Edo Rajh, Ljiljana Božić, „Razvoj mjerne ljestvice za mjerenje percipiranog intenziteta sponzorskih aktivnost“, u: Market-Tržište, Zagreb, vol. XVIII/2006., br. $1 / 2$, str. 8 .

20 Usp. Bettina T. Cornwell, Isabelle Maignan, „An International Review of Sponsorship Research“, u: Journal of Advertising, vol. 27, br. 1, 1998., str. 14.

21 Isto.

22 Usp. L. Dadić, nav. dj., str. 82. 
Charities Aid Foundation ${ }^{23}$ (CAF) od 2010. godine objavljuje Sujetski indeks davanja (World Giving Index) kojim prati opseg i kulturu davanja širom svijeta. Svjetski indeks davanja oslanja se na tri kriterija, odnosno područja ljudskoga ponašanja:

- pomaganje nepoznatima

- darivanje novca u dobrotvorne svrhe i

- odvajanje vremena za volontiranje.

Ovaj indeks pruža jedinstven uvid u trendove velikodušnosti diljem svijeta. Metoda koja se koristi za izračunavanje indeksa davanja CAF-a u svijetu nepromijenjena je od početka, a operativno istraživanje provodi tvrtka za istraživanje tržišta Gallup. Svaka zemlja dobiva postotni rezultat, te se rangiraju na temelju tih rezultata. Rezultati se osim usrednjavanja (prosjek tri područja) donose i pojedinačno za svako područje. Indeks pružanja usluga CAF 2018. sadrži podatke iz 146 zemalja koji su prikupljeni tijekom 2017. godine. ${ }^{24}$

Prema CAF World Giving Indexu 2018. zemlja s najvišim postotkom donatora je Mjanmar (88 \%), slijede Indonezija (78 \%), Australija (73 \%) i Velika Britanija (68 \%). U Hrvatskoj godišnje donira tek $25 \%$ građana, što je svrstava na 72 . mjesto u ovoj kategoriji, a ukazuje i na nedovoljno razvijenu kulturu darivanja novca u dobrotvorne svrhe. Postotak u drugim dvjema kategorijama još je niži, pa je World Giving Index za Hrvatsku tek 20 \%, što je svrstava tek na 132. mjesto. Bosna i Hercegovina prema ovom je parametru na visokom 34. mjestu (40\%), ukupno u sve tri kategorije na 90. mjestu (28\%). Najmanje ljudi donira u Jemenu (2\%) i Maroku (5\%), a od europskih zemalja najmanje se donira u Grčkoj $(7 \%) .{ }^{25}$

Što se dobne strukture darivatelja tiče, ovo izvješće pokazuje da oni koji su stariji od 50 godina doniraju približno jednako kao i oni u dobi od 30 do 49 godina, a postotak doniranja u obje dobne skupine u padu je u odnosu na izvješća prethodnih godina (grafički prikaz 2). Udio mlađih ljudi (u dobi od 15 do 29 godina) koji doniraju novac širom svijeta ostaje stabilan, na otprilike četvrtini ukupne populacije. U razvijenim zemljama, stariji od 50 godina i dalje značajno češće doniraju novac od svojih mlađih kolega. U gospodarstvima u razvoju i zemljama u tranziciji najvjerojatnije ce donirati dobna skupina od 30 do 49 godina. U razvijenim zemljama najviša

23 Charities Aid Foundation (CAF) vodeća je međunarodna dobrotvorna organizacija registrirana u Velikoj Britaniji, s devet ureda na šest kontinenata.

24 Usp. cafonline.org/docs/default-source/about-us-publications/caf_wgi2018_ report_webnopw_2379a_261018.pdf

25 Usp. isto. 
je razina sudjelovanja mlađih osoba (35 \% naspram $23 \%$ za tranzicijske zemlje i $22 \%$ za zemlje u razvoju). U razvijenim zemljama $46 \%$ osoba starijih od 50 godina doniralo je novac, a $35 \%$ u dobi od 15 do 29 godina. ${ }^{26}$

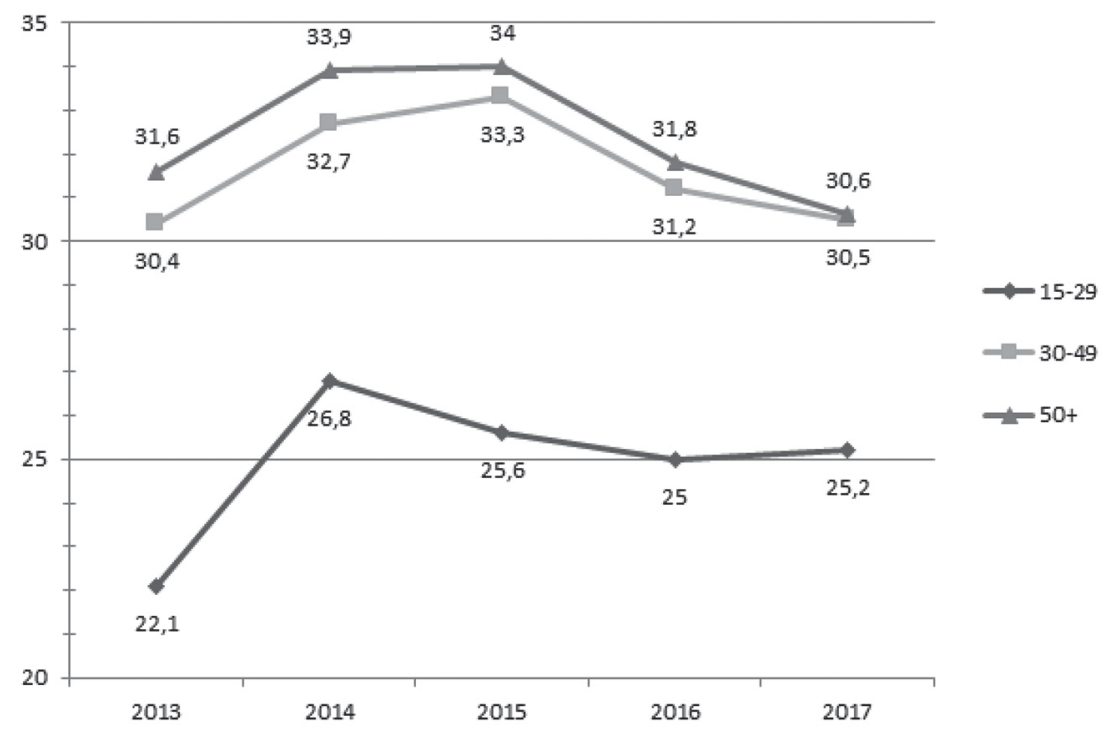

Grafički prikaz 2. Globalni udio u doniranju novca prema dobi

Istraživanje pokazuje da je vrlo mala razlika u broju žena i muškaraca koji doniraju, muškarci doniraju 0,2 \% više od žena. Zemlje u kojima je vjerojatnije da će muškarci donirati novac od žena, su Kosovo (gotovo 21 \% razlike), Ujedinjena Republika Tanzanija i Pakistan (razlika od $19 \%$ ). Zemlje u kojima žene češće doniraju novac su Švedska, Novi Zeland i Norveška. ${ }^{27}$

\section{PARTNERSTVO S DONATORIMA I SPONZORIMA}

Prikupljanje sredstava složen je proces, koji se sastoji od niza međusobno povezanih aktivnosti, a treba mu pristupiti profesionalno i sustavno. Temeljna vrijednost fundraisinga potencijalni su i

\footnotetext{
26 Isto.

27 Usp. isto.
} 
postojeći donatori i sponzori. Važno pitanje koje svaka organizacija treba postaviti, jest kako utjecati na donatore i zašto bi oni donirali baš određenoj neprofitnoj organizaciji. ${ }^{28}$

Dobro je da neprofitne organizacije uspostave dugoročne odnose s donatorima. Za uspješno prikupljanje sredstava neizostavan je jasno definiran razlog za potporu (case for support). On je najvažniji argument za filantropsku potporu i bez njega neprofitne organizacije ne trebaju ni započinjati prikupljati sredstva. Riječ je o odgovoru na pitanje zašto određena organizacija ili njezin projekt zaslužuju potporu. ${ }^{29}$

Temeljne aktivnosti fundraisinga obuhvaćaju: prepoznavanje perspektiva, definiranje potreba, prenošenje zahtjeva i izgradnju odnosa. Važno je napomenuti da su sve te aktivnosti međusobno povezane $i$ isprepletene te da se mogu odvijati paralelno. ${ }^{30}$

Prepoznavanje perspektiva pretpostavlja sagledavanje trenutnih izvora financiranja i uočavanje potencijalnih donatora. Ovdje je potrebno odgovoriti na pitanja: tko su potencijalni donatori, kakav je njihov dosadašnji kontakt $s$ organizacijom i zašto bi oni odlučili donirati. Definiranje potreba podrazumijeva utvrđivanje potrebne visine financijskih sredstava i izvora financiranja. Prenošenje zahtjeva može se promatrati u kontekstu komunikacijskog kanala s potencijalnim donatorima. Uspješnost fundraisinga ovisi o moći prenošenja zahtjeva. Najučinkovitijim se smatra osobni kontakt $\mathbf{s}$ potencijalnim donatorima, pri kojem je bitno predstaviti organizaciju, željene rezultate i ciljeve. Pozitivan imidž organizacije, kao i pozitivna energija, svakako će najviše utjecati na odluku o doniranju. Izgradnja odnosa obuhvaća kontinuiranu komunikaciju s donatorima, stvaranje prijateljstva s njima, iskazivanje zahvalnosti i poštovanja, upoznavanje donatora s programima i osobljem organizacije, izgradnju partnerskih mreža i dr. ${ }^{31}$

Prije nego što se pristupi izvorima financiranja poželjno bi bilo razmotriti tko su donatori - u kojem bi obliku mogli pružiti potrebnu podršku. Korisno bi bilo napraviti bazu podataka o postojećim i potencijalnim donatorima i sponzorima koja bi sadržavala njihove profile i kontakte te povijest odnosa s organizacijom. Prilikom traženja financijskih sredstava treba precizno zahtijevati visinu donacije i razloge zbog kojih baš vaš zahtjev zaslužuje podršku potencijalnih

\footnotetext{
28 Usp. L. Dadić, nav. dj., str. 82.

29 Usp. N. Alfirević, i dr., nav. dj., str. 130.

30 Usp. L. Dadić, nav. dj., str. 83.

31 Usp. isto.
} 
donatora. Zato pri kreiranju zamolbe treba izbjegavati frazeme kojima se šalje signal da nije utvrđena konkretna potreba vaše organizacije kao što su primjerice: donirajte koliko možete; cijenili bismo donaciju u iznosu od 200 do $2000 \mathrm{kn}$ i sl. Za uspješno prenošenje zamolbe potrebno je izabrati najprimjereniju osobu, odnosno onu koja s donatorom dijeli način razmišljanja i osobne vrijednosti. Važno je donatorima pružiti osjećaj da su dali svoj doprinos nečemu značajnom, a to bi zapravo bilo doniranje sredstava vašoj organizaciji. Jedna od efikasnijih metoda za upoznavanje s potencijalnim novim donatorima organiziranje je specijaliziranih medijski dobro popraćenih i široj javnosti zanimljivih događanja (event) koja pomažu da se:

- $\quad$ s donatorima lakše uspostave i izgrade odnosi

- donatori osjete jače povezanima s misijom neprofitne organizacije

- $\quad$ stvore bolji uvjete za osiguranje donacija u budućnosti i

- unaprijedi profil neprofitne organizacije u društvenoj zajednici. ${ }^{32}$

Iskazivanje priznanja osobni je, ali i javni čin, stoga se potrebno pridržavati donatorovih želja i sačuvati njegovu anonimnost ako on to želi.

Za održavanje odnosa s donatorima potrebno je biti umjeren i stalno širiti krug, ne „eksploatirati“ uvijek iste podupiratelje, pokušati ih pridobiti da se osobno prepoznaju u ciljevima i projektima neprofitne organizacije te im tako pomoći da ostvare svoj društveno koristan angažman za koji imaju sredstava, ali ne i vremena da ga sami realiziraju. Unaprijed je dobro poći od činjenice da se većina pojedinaca i tvrtki želi angažirati u humanitarnom i društvenom području, a na članovima i vodstvu organizacije zadatak je pronaći i pridobiti one koji se mogu i žele poistovjetiti s ciljevima organizacije i pružiti joj konkretnu pomoć.

S donatorima treba održavati službeni odnos, bez prijelaza na prijateljsku razinu. Stvaranje osobnog prijateljstva moguće je, no treba prepustiti donatoru da on prvi iskaže zanimanje za to. ${ }^{33}$

Pri iskazivanju zaslužene zahvalnost donatoru potrebno je pripaziti na pet važnih pravila:

1. Ne ponašati se kao da je financijska potpora očekivana, da je to bila donatorova obveza.

2. Naglasiti koliko je značajna njegova potpora.

32 Usp. Bernard Iljazović, „Komunikacija i partnerstvo s donatorima“, u: Udruga, Zagreb, br. 28/2017., str. 18-20.

33 Isto. 
3. Pohvaliti njegovu društvenu osjetljivost i istaknuti kako će njegov primjer potaknuti i druge pojedince ili organizacije.

4. Zahvaliti na potpori u realizaciji prethodnih projekata i ne spominjati moguću potporu u budućnosti.

5. Ne pokazati nezadovoljstvo donacijom, bez obzira na to koliko ona bila mala. ${ }^{34}$

Koga pitati za sponzorstvo? Potrebno je uspostavljati i održavati kontakte sa sponzorima i donatorima i prije nego što vam zatrebaju. Nije isto tražiti sponzorstvo od malih ili od velikih tvrtki. Velike su tvrtke izloženije zahtjevima za sponzorstvo pa imaju razrađen sustav prijavljivanja, godišnje natječaje s kriterijima i preciznim rokovima te upute na svojim web stranicama. Manje tvrtke nemaju poseban odjel marketinga pa je potrebno pronaći osobu koja obavlja i taj dio posla te joj se izravno obratiti. Treba voditi računa o tome da nisu svi sponzori i donatori primjereni za vašu organizaciju. Uvijek je potrebno djelovati u skladu s vizijom, misijom i etičkim načelima organizacije. ${ }^{35}$

Sponzori mogu izabrati: iz proračuna predviđenoga za promidžbu mogu platiti oglas u novinama, reklamu na televiziji, sami organizirati neko događanje ili ga dati nekoj drugoj neprofitnoj organizaciji. Osoba koja čita dopise s pozivima na sponzorstvo ima vrlo malo vremena. Stoga je poziv na sponzorstvo potrebno prilagoditi svakom potencijalnom sponzoru, istaknuti ono što bi njemu moglo biti zanimljivo, a ukloniti ono što ne bi, ne opterećujući ga nepotrebnim informacijama. ${ }^{36}$

\section{TROŠKOVI KAMPANJE I KONTROLA PRIKUPLJENIH SREDSTAVA}

Glavni cilj traženja prostora za uštedu podizanje je kvalitete, a da se pritom ne plaća ono što nije potrebno i bez čega je moguće jednako dobro funkcionirati. Neke se uštede mogu činiti presitnima da bi se njima bavili, ali ne postoje mali i veliki troškovi, postoje samo potrebni i nepotrebni. ${ }^{37}$ Treba nastojati smanjiti troškove prikupljanja financijskih sredstava koliko god je to moguće, jer potencijalni donatori žele znati je li organizacija sposobna učinkovito koristiti njihove donacije.

\footnotetext{
34 Isto.

35 Usp. O. Štajdohar-Pađen, nav. dj., str. 14-15.

36 Isto, str. 15-16.

37 Usp. Olga Štajdohar-Pađen, „Novac dolazi na dvije noge a odlazi na stotinu“, u: Udruga, Zagreb, br. 30/2017., str. 13-14.
} 
Neprofitne organizacije imaju neposredne i posredne troškove. Neposredni su troškovi kod prikupljanja sredstava plaće, honorari i beneficije. Posredni se troškovi odnose na iznajmljivanje, zakup ili hipoteku prostora, održavanje opreme i dr. ${ }^{38}$

Zbog lošeg upravljanja troškovima u neprofitnim organizacijama može doći do problema u odnosima s javnošću. Postotak prikupljenih sredstava koji se potroši na samu kampanju može izazvati negativnu reakciju javnosti. Neke kampanje koštaju oko 25 \% prikupljenih sredstava. Negativan publicitet povezan s visokim troškovima kampanje može negativno utjecati na učinkovitost organizacije u prikupljanju sredstava, jer ona najčešće ovise o potpori javnosti. Uobičajena visina troškova kampanje ne bi smjela prelaziti 12-15\% prikupljenih sredstava, a troškovi do $20 \%$ postali su gornja prihvatljiva razina za one koji traže i troše donirana sredstva. Primjerice, Fort Worth, grad u Texasu, zabranjuje neprofitnim organizacijama prikupljati sredstva ako im troškovi kampanje prelaze $20 \%$ ukupnoga proračuna akcije. Kod prikupljanja sredstava potrebno je voditi brigu o etičkim standardima i kontroli troškova. Brojne nevladine organizacije upravo su na etičkim standardima izgubile reputaciju u javnosti i tako nestale sa scene te nanijele štetu cijelom sektoru.

\section{MARIJINI OBROCI (MARY'S MEALS) - PRIMJER DOBRE PRAKSE}

Jedan od dobrih primjera aktivnog prikupljanja sredstava, učinkovita korištenja i niskih troškova poslovanja međunarodna je humanitarna organizacija Mary's Meals (Marijini obroci), a u praksi se često naziva i Mary's Meals International, ili skraćeno MMI.

Marijini obroci naziv je dobrotvorne organizacije koja se prethodno zvala Scottish International Relief (SIR). Cilj je organizacije osigurati prehranu u školama u nekim od najsiromašnijih država svijeta. U tim državama djeca i mladi zbog siromaštva i gladi ne pohađaju škole, a organizacija Marijini obroci pomaže im da se mogu prehraniti i školovati. Sve je započelo 1992. godine, tijekom rata na prostoru bivše Jugoslavije, kada su škotski mladići Magnus i Fergus MacFarlane-Barrow organizirali prikupljanje pokrivača i hrane. Osobno su odvezli prikupljene potrepštine u Međugorje. Planirali su se vratiti poslu u uzgajalištu riba. No nastavili su dobivati donacije, pa se Magnus odlučio nastaviti baviti humanitarnim radom te je nakon nekoga vremena osnovao humanitarnu organizaciju nazi-

38 Usp. William Byrnes, Menadžment i umetnost, Clio, Beograd, 2009., str. 513-514. 
va Scottish International Relief. Dana 1. svibnja 2012. Scottish International Relief promijenio je ime u Mary's Meals. Ljudima koji su bili uključeni u prve projekte živote su promijenila hodočašća u Međugorje te su organizaciju odlučili nazvati u čast Mariji, Isusovoj majci. ${ }^{39}$ Organizacija okuplja ljude svih vjera, ali i ateiste, te $u$ tom smislu svima želi pomagati. Sjedište joj je u mjestu Dalmally u Škotskoj, a podružnice joj se nalaze u Hrvatskoj, BiH, Njemačkoj, Italiji, SAD-u, Australiji, Austriji, Irskoj, Španjolskoj, Francuskoj, Nizozemskoj, Kanadi i Češkoj. ${ }^{40}$ MMI je tvrtka s ograničenom odgovornošću koja je regulirana Memorandumom i Statutom od 3. listopada 2014. Registrirana je kao dobrotvorna organizacija pri uredu škotskog regulatora za dobrotvorne organizacije. ${ }^{41}$

Marijini obroci u $\mathrm{BiH}$ imaju sjedište u Međugorju, svojevrsnu ishodištu organizacije, gdje djeluju kao podružnica, dok u Hrvatskoj djeluju kao udruga od srpnja 2009. godine. Danas Marijini obroci Hrvatska, zahvaljujući dobroti svojih podupiratelja, hrane više od 11.400 najsiromašnije djece svijeta u školskim kuhinjama u Liberiji, Malaviju, Beninu i Ekvadoru. ${ }^{42}$

Od ukupnih troškova prikupljanja sredstava (samo 7 \% od ukupno prikupljenih sredstava) u 2018. godini na troškove zaposlenika otpada $72 \%$ (2017.: 66,3 \%), na troškove imovine 3,4 \% (2017.: $2,6 \%$, uredske troškove 18,8 \% (2017.: 28,2 \%), prijevoz i putovanja 4,1 \% (2017.: 2,6 \%), i na amortizaciju 1,7\% (2017.: 0,4\%). ${ }^{43}$

Prva akcija ove organizacije bila je osiguranje hrane za 200 školske djece u Malaviju. Tijekom vremena projekt se znatno proširio i danas pruža besplatne školske obroke u stotinu škola te hrani više od 1.667.067 djece dnevno diljem Afrike, Azije, Europe, Južne Amerike i Kariba (28. 7. 2020.), a s obzirom na veliko siromaštvo u zemljama u kojima trenutno djeluje potrebno je samo $132 \mathrm{kn}$ (oko 30,5 KM, 12,2 £, 15,6 €) da bi se prehranilo dijete tijekom cijele školske godine. ${ }^{44}$ Jedan obrok poslužen na mjestu obrazovanja stoji samo 50 lipa.

39 Usp. https://www.marysmeals.hr/korisne-poveznice/o-marijinim-obrocima/ (23. rujna 2019.)

40 Usp. https://www.marysmeals.hr/tko-smo-mi/nasa-povijest/ (27. svibnja 2020.)

41 Usp. https://www.marysmeals.cz/assets/local/MMI_Annual_Report_2018.pdf. (3. lipnja 2020.)

42 Usp. https://www.marysmeals.hr/ (27. svibnja 2020.)

43 Usp. isto.

44 Usp. https://www.marysmeals.hr/ukljucite-se/prikupljanje-sredstava/ (28. svibnja 2020.). 
Vizija je organizacije Marijini obroci da svako dijete prima jedan dnevni obrok na mjestu obrazovanja i da svi oni koji imaju više nego što im je potrebno podijele $s$ onima kojima nedostaju i najnužnije stvari. Marijini obroci također vode dom u Rumunjskoj za mlade s HIV-om koji su bili odbačeni u djetinjstvu. Kako navodi Magnus MacFarlane-Barrow, osnivač Marijinih obroka, njihova je misija omogućiti ljudima da doniraju novac, proizvode, vještine, vrijeme ili molitve te tako pruže najučinkovitiju pomoć onima koji trpe ekstremno siromaštvo u najsiromašnijim zajednicama svijeta. Gotovo svaki dio njihova rada ovisi o neplaćenim volonterima te njihov pokret raste upravo preko njih. ${ }^{45}$

Prema MacFarlane-Barrowu od svake donirane kune najmanje 93 \% troše na dobrotvorne aktivnosti. Marijini obroci pokrenuti su iz montažne limene kućice. Do današnjega dana, unatoč tome što su se razvili u organizaciju globalnih razmjera, ta je montažna kućica još uvijek njihovo sjedište. Troškove poslovanja žele održati što nižima, kako bi povećali dobro donacijama koje su im povjerene. Troše najviše 7 \% doniranoga na upravljanje i prikupljanje sredstava. To je moguće samo zato što njihov posao obavlja velik broj posvećenih volontera u zemljama u kojima djeluju. Za ilustraciju, u Malaviju ima više od 80.000 volontera koji se izmjenjuju u pripremi, kuhanju i posluživanju svakodnevnih obroka u školama. ${ }^{46}$ Zbog vjerodostojnosti koju postižu afirmacijom tih činjenica (ispodprosječni troškovi, uključenost volontera, mnogobrojnost djece koju hrane i školuju) njihov ugled svakodnevno raste, a povjerenje koje imaju na globalnoj razini rezultira lakšom mobilizacijom pojedinačnih i malih donatora, kao i onih velikih.

Prema godišnjem izvješću za 2018. godinu organizacija je u toj godini zabilježila ukupni višak od 6.296 milijuna funta (u usporedbi sa 2017. godinom, kada je višak bio 4.124 milijuna funta). Ukupni prihod te godine bio je 26.059 milijuna funta (2017.: 24.235 milijuna funta). Većina prihoda ostvarena je u podružnicama širom svijeta, pri čemu čak $62 \%$ (2017.: $61 \%$ ) ukupnog novčanog prihoda dolazi od nacionalne podružnice u Velikoj Britaniji, 15 \% (2017.: $17 \%$ ) od nacionalne podružnice $\mathrm{u} \mathrm{SAD-u}$, a preostala sredstva generiraju se u mnogim drugim nacionalnim podružnicama, međunarodnim skupinama za prikupljanje sredstava i donacijama pojedinaca širom svijeta. Među vrlo aktivnim podružnicama je i ona u Hrvatskoj, na visokom šestom mjestu po prikupljenim sredstvima u 2018. godini,

45 Isto.

46 Usp. https://www.marysmeals.hr/cime-se-bavimo/gdje-radimo/malavi (27. svibnja 2020.). 
sa $1,95 \%$ (2017.: 1,9 \%) od ukupno prikupljenih sredstava. Ukupni izdaci MMI-a za isto razdoblje iznosili su 19.915 milijuna funta (2017.: 19.760 milijuna funta). ${ }^{47}$

Na službenoj web stranici Marijinih obroka ističu:

Vjerujemo u dobro upravljanje svim sredstvima koja su nam povjerena i cilj nam je otvorenost i odgovornost prema svim našim podupirateljima i svima koji su uključeni u ovaj rad. Kontinuirano uspijevamo održati svoje obećanje o usmjeravanju najmanje 93 lipe od svake donirane kune izravno u humanitarne aktivnosti. ${ }^{48}$

O posljedicama činjenice da velike međunarodne organizacije često pomoć i hranu dostavljaju u velike gradove siromašnih zemalja MacFarlane-Barrow kaže:

Kad smo sve odvagnuli, odlučili smo nastaviti svoja nastojanja u ruralnim područjima umjesto u gradu. Vidjeli smo da se većina humanitarnih organizacija usredotočuje na gradove, dok su sela zanemarena i još siromašnija. Željeli smo učiniti sve što je u našoj moći kako bismo potaknuli zemljoradnike da se vrate na svoja imanja, radije nego da doprinosimo razlozima da ljudi ostaju u gradu. ${ }^{49}$

Marijini obroci nastoje ne samo prehraniti djecu u siromašnim zemljama u kojima djeluju te im tako spasiti život i dati temeljno obrazovanje, nego nastoje $\mathrm{i}$ iskorijeniti siromaštvo u tim sredinama, otkupljujući hranu od lokalnih proizvođača koji zahvaljujući Marijinim obrocima imaju tržište. Tako pojeftinjuju nabavu potrebnih namirnica jer su tako smanjeni i troškovi transporta i dostave.

Prema istraživanju o utjecaju Marijinih obroka provedenom u Malaviju, Zambiji i Liberiji, udio djece koja su rekla da su gladna „većinu dana“ ili „uvijek“ pao je za $71 \%$. Zahvaljujući Marijinim obrocima bilježi se 20-postotni porast upisa djece u školu, udio djece kojima je teško usredotočiti se na nastavi pao je za 52 \%, a broj djece koja su zabrinuta zbog gladi smanjio se za $64 \%$. Koristi Marijinih obroka višestruke su: smanjenje gladi, omogućavanje obrazovanja, uključenost lokalne zajednice i roditelja. ${ }^{50}$

47 Usp. https://www.marysmeals.cz/assets/local/MMI_Annual_Report_2018.pdf. (3. lipnja 2020.)

48 https://www.marysmeals.hr/tko-smo-mi/kako-trosimo-donacije/ (23. rujna 2019.)

49 Magnus MacFarlane-Barrow, Baraka koja je nahranila milijun djece, Verbum, Split, 2016., str. 158.

50 Usp. https://narod.hr/hrvatska/video-marijini-obroci-prazan-trbuh-nema-usipomozite-gladnu-djecu-svojom-donacijom (23. rujna 2019.) 
MMI dosta polaže na odnose s javnošću, na svojim web stranicama ističu da je komunikacija jedan od ključnih elemenata rasta ovog globalnog pokreta. Angažiraju simpatizere pokreta na promociji svoga rada, poznate osobe (npr. Gerard Butler), surađuju na snimanju dokumentarnih filmova o MMI-u, film Dijete 31 napravio je velik promotivni učinak za organizaciju, knjiga utemeljitelja pokreta Magnusa MacFarlane-Barrowa Baraka koja je nahranila milijun djece $^{51}$ prevodi se svake godine na nove jezike, podružnice diljem svijeta organiziraju gala-koncerte i humanitarne utrke (npr. Trčimo za dijete 31), članovi nastupaju na međunarodnim festivalima i konferencijama promovirajući MMI, ali i samu ideju volonterstva i humanitarnog djelovanja. ${ }^{2}$

Zbog dobre reputacije pokret sve više raste, broj djece kojima pomažu iz dana u dan sve je veći, no navode da u svijetu ima 61 milijun djece koja ne idu u školu i koja su kronično gladna, te se ne zadovoljavaju postignutim rezultatima i ističu da njihov posao tek počinje. ${ }^{53}$

\section{ZAKLJUČAK}

Prikupljanje sredstava (fundraising) dugotrajan je i zahtjevan proces koji sadrži više međusobno povezanih aktivnosti, a treba mu pristupiti profesionalno i sustavno. Svaka organizacija treba postaviti pitanja kako utjecati na donatore te zašto bi oni donirali baš određenoj neprofitnoj organizaciji.

Za učinkovito prikupljanje sredstava potrebno je zapamtiti da ono nije cilj sam po sebi, već treba biti nadahnuto ostvarivanjem konkretnih ciljeva organizacije. Tako će biti poticajno i onima koji nastoje prikupiti sredstva kao i onima od kojih se prikupljaju. Polazište uvijek treba biti ostvarivanje ciljeva, a ne prikupljanje sredstava, iako su ona nužna za njihovo ostvarenje.

Osim o učinkovitom prikupljanju potrebno je voditi računa o učinkovitom korištenju prikupljenih sredstava te što nižim troškovima njihova prikupljanja i distribucije.

Globalna humanitarna organizacija Marijini obroci te je troškove svela na najmanju moguću mjeru (najviše $7 \%$ ) te takvom reputacijom olakšavaju dodatno prikupljanje sredstava i učinkovito djelovanje.

51 U Hrvatskoj objavljena 2016., Verbum Split.

52 Usp. https://www.marysmeals.cz/assets/local/MMI_Annual_Report_2018.pdf. (3. lipnja 2020.)

53 Usp. https://www.marysmeals.hr/ (4. studenog 2018.) 


\section{FUNDRAISING, CAMPAIGN COSTS, AND CONTROL OF COLLECTED FUNDS IN THE EXAMPLE OF THE INTERNATIONAL CHARITABLE ORGANIZATION MARY'S MEALS}

\section{Summary}

Fundraising is a very important activity of non-profit organizations because without financial means it would be difficult for them to realize their mission. Often in non-profit organizations the obligation to plan the fundraising is the work of public relations employees. For successful fundraising, it is essential to have a clearly defined case for support. Negative publicity associated with campaign costs can affect the organizations' efforts in fundraising, as they most often depend on public support. The usual campaign costs should not exceed $12-15 \%$ of the total funds raised, and the costs up to $20 \%$ have become the highest acceptable level. Fundraising must be accompanied by commitment to ethical standards and cost control. Numerous non-governmental organizations have lost their reputation precisely on ethical standards, vanished from the scene and inflicted damage on the entire non-profit and humanitarian sector. One of the most striking examples of good fundraising performance and efficient use of the funds collected, is the international humanitarian organization Mary's Meals.

Keywords: non-profit organizations, fundraising, donations, sponsorships 